\title{
NIH panel to limit secrecy on gene therapy
}

Washington

The US government advisory committee that monitors experiments in human gene therapy plans to act early next month to stiffen its guidelines on the reporting of deaths and adverse events.

The action by the Recombinant DNA Advisory Committee (RAC) of the National Institutes of Health (NIH) follows attempts by a leading researcher and a drug company to keep confidential a death and serious side effects, respectively, suffered by gene therapy patients.

Current RAC guidelines require scientists to report any serious adverse event immediately to the NIH's Office of Recombinant DNA Activities (ORDA), which staffs the RAC. But they do not say whether such reports can be marked 'confidential', and thus kept off the RAC's public agenda. The committee aims to remove this option.

"Trying to hold these confidential may be of short-term benefit for some reasons for the company. But in the long term it's [not] in the best interests of the field," says Claudia Mickelson, the RAC chair and institutional biosafety officer at the Massachusetts Institute of Technology.

The RAC decision followed a meeting in September, at which it was presented with a letter sent to ORDA in May 1998. In the letter, stamped confidential, Ronald Crystal, a gene therapist at the New York Hospital-Cornell Medical Center, reports - but gives no details of - the death of a 61-year-old man during a gene therapy trial aimed at inducing the growth of new heart blood vessels.

Crystal states that the death, 40 days after

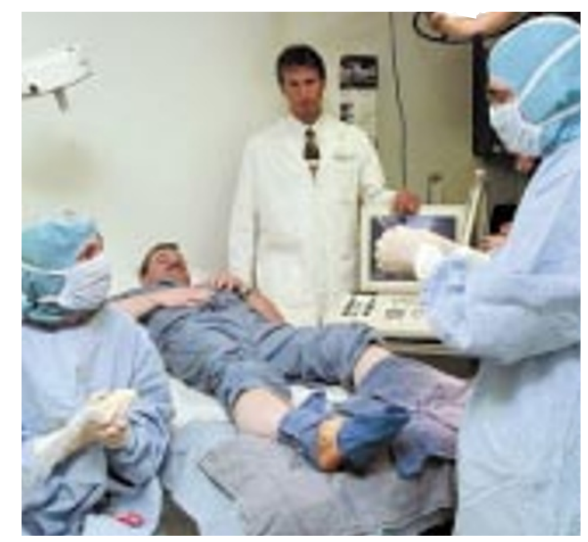

Keeping it public: a patient awaits gene therapy for muscular dystrophy.

gene therapy was administered, was not linked to the therapy. He requests that the letter "be kept confidential and not part of the public record". Crystal reported fully on the case at the 1998 conference of the American Heart Association, and in the 3 August 1999 issue of the journal Circulation.

Crystal says that he asked for secrecy to protect the patient's family. He adds that the RAC is understaffed, and ill-equipped to judge whether the death was related to the gene therapy. "I was very concerned about releasing confidential patient information in the context of a group that has neither the appropriate secrecy nor the expertise and manpower to evaluate it."

Crystal wrote the letter around the time that the Rockville-based biotechnology company that he founded, GenVec, filed to make an initial public stock offering. But he says that the two events were unrelated, and that his interest in the company was 1.5 per cent of an enterprise valued at the time at about $\$ 70$ million. Company officials ultimately decided not to go public.

In a separate incident, the drug company Schering-Plough reported to ORDA in September, describing two patients who had developed side effects in gene therapy trials for colorectal and ovarian cancer. "Some of this information is proprietary competitive information," Bob Consalvo, a company spokesman, said in a statement last week.

NIH officials say that these are not isolated cases. In a research area once funded largely by public money, but now almost totally reliant on industry, a number of investigators and their sponsors are asking for elements of protocols - and sometimes entire protocols - to be confidential.

The RAC has always allowed proprietary information to be kept confidential. But secrecy requests involving deaths and side effects go against the spirit of a fledgling field that has sought to gain public trust through openness. In September, for example, the death of an 18-year-old man in a gene therapy protocol was fully reported by James Wilson, of the University of Pennsylvania (see Nature 401, 517; 1999).

NIH officials, however, tread a fine line in seeking to keep the field transparent. If too much is revealed, they risk scaring away commercial sponsors. "The challenge is to figure out a way that we can put patients first and still preserve the commercial interest in this field that has vitalized it," says Amy Patterson, the ORDA director. Meredith Wadman

\section{Protests grow over interrogation of Ukraine scientists}

London

Ukraine's secret services have widened their investigation into staff at the Institute of Biology of Southern Seas (IBSS), following the arrest of marine biologist Sergei Piontkovski on charges of sending 'secret' information abroad and handling foreign currency illegally. Meanwhile a growing number of international organizations have protested about the action (see Nature 401, 835 ; 1999).

Ten IBSS staff have now been questioned by Sebastopol security services (USBU). All were participants in either a UK-funded Darwin Initiative project or a Europeanfunded INTAS project. The grants from these projects, for the collection of biodiversity data, appear to be the focus of the intelligence operation. INTAS says other grant recipients in southern Ukraine have been asked to report to USBU.
INTAS, which promotes cooperation with scientists from the independent states of the former Soviet Union, said last week that it was "shocked" at Piontkovski's detention. The Ukrainian Ministry of Science and INTAS have confirmed that Piontkovski's work was done in agreement with the Ukrainian government and in accordance with the law. An official reaction from the government is still awaited.

Elisa Muñoz, of the committee on scientific freedom and responsibility of the American Association for the Advancement of Science, says she will ask the committee's network of scientists to write to the Ukrainian authorities to request Piontkovski's unconditional release.

The European Commission has requested an explanation from the same authorities, and the International Council for Science's committee on oceanic research

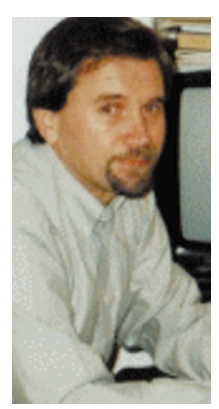

Piontkovski:

fears a charge of espionage. is writing to the Ukrainian Academy of Sciences. A friend of Piontkovski's has set up a website on the case (http://www.geocities. com/sep_case/). On it, a fax from the Ukrainian science ministry to the head of the security services warns that the action could have "negative consequences for the international scientific collaboration of Ukraine".

Piontkovski was held in USBU offices for four days and subjected to interrogations that he says were "long term and with unpleasant dialogue with a lot of threats that [the charge] would fall into the category of espionage actions".

Natasha Loder 